addition to the usual exhibition of books, it is hoped to arrange an exhibition on teaching-aids in primary and secondary schools and another one on modern calculating machines. All arrangements for the meeting are in the hands of the local secretary, $C$. R. Barwell, 53 Duke's Drive, Newbold, Chesterfield, from whom further information can be obtained.

\section{Scientific Film Association}

At the annual general meeting of the Scientific Film Association, the following officers were elected for the year 1953-54: President, Sir Arthur Elton; Vice-President, W. J. C. Chapple; and Honorary Treasurer, K. Baron Hartley. As a result of recent changes in the articles of association, the council of management will in future consist of the officers, six elected members and seven members nominated by the Lord President of the Council to represent general scientific and public opinion. The elected members are B. Chibnall, Dr. R. C. MacKeith, J. Maddison, C. A. Ronan, C. H. Sylvester and R. A. Williams; the members nominated by the Lord President are Mrs. Jacquetta Hawkes, Dr. F. H. K. Green (Medical Research Council), Dr. Alexander King (Department of Scientific and Industrial Research), Sir Ian OrrEwing, J. Ryan, Sir William Slater (Agricultural Research Council) and Sir Robert Watson-Watt. The address of the Association is 164 Shaftesbury Avenue, London, W.C.2.

\section{Direct Reading Emission Spectroscopy}

THE Industrial Spectroscopy Group of the Institute of Physics has formed a panel of members interested in direct-reading equipment for spectrochemical analysis. These devices combine spectrographs with electronic equipment in such a way that the intensities of characteristic spectral lines give a direct reading of the percentage of the elements present in the specimen. The object of the panel is to organize meetings which would serve the interests of users and potential users of this equipment. The first meeting arranged by the panel took place in the Institute's House on March 26 last, when Dr. A. C. Menzies introduced the subjeet. Mr. A. L. Pendrey and Mr. R. T. Staples gave accounts of their experiences in this type of work, and there followed a general discussion. Particulars relating to meetings on this subject can be obtained from the Secretary, Institute of Physics, 47 Belgrave Square, London, S.W.1

\section{Handbook of Scientific Instruments and Apparatus}

THE annual "Handbook of Scientific Instruments and Apparatus", giving details of the exhibits at the Physical Society's annual exhibition, is now a publication familiar to all men of science and manufacturers of scientific instruments. This year's exhibition, the thirty-seventh of the series, is to be held at the Imperial College of Science and Technology, South Kensington, London, during Monday, April 13Friday, April 17, and will be opened on April 13 at 10.30 a.m. by Prof. R. Whiddington, president of the Physical Society. Three discourses are being given this year: (1) Dr. E. C. Bullard (director of the National Physical Laboratory) on "Seismic Study of the Ocean Basins" ; (2) Dr. L. A. Jordan (director of the Paint Research Station) on "Particles, Pellicles; Pigments, Paints and Physics"; and (3) Prof. W. V. Mayneord (Department of Physics, Royal Cancer Hospital) on "Scintillation Counting and its Medical Applications". The prize distribution of the Crafts- manship and Draughtsmanship Competition will take place during the exhibition on April 13 at 5 p.m. The handbook, a volume essential to all workers interested in the progress and development of scientific instruments, gives instructive descriptions of the many instruments shown by about a hundred and fifty exhibitors, including government research establishments. This extremely useful volume, which is now available, is printed on glossy paper and is illustrated by numerous half-tone reproductions of scientific instruments. It should be in the hands of all physicists and scientific workers who use or design scientific instruments (pp. xii $+262+$ A72. Physical Society, 1 Lowther Gardens, Prince Consort Road, London, S.W.7. $6 s$, or $7 s .3 d$. post paid).

\section{Announcements}

Sir HenRy BerEsford-Peirse, director of forestry for Scotland since 1947, has been appointed deputy director-general of the Forestry Commission. He will be succeeded in Scotland by Mr. A. H. H. Ross, at present conservator of forests for north-west England.

THE following have been appointed lecturers in the Queen's University of Belfast: S. McConaghy (agricultural chemistry), R. E. Parker and Dr. E. W. Simon (botany), and Dr. I. Leslie (biochemistry).

The Commonwealth Fund (35 Portman Square, London, W.1) has awarded the following Home Civil Service Fellowships to British Civil servants for study in the United States during 1953-54: B. R. Feaver (Forestry Commission (Scotland)), G. Leitch (Ministry of Supply), L. S. Mills (Ministry of Civil Aviation) and P. E. Watts (Ministry of Fuel and Power).

ThE Bone and Tooth Society will hold a symposium on "Vitamin C and Bone" on April 9 at the Institute of Orthopædics, 234 Great Portland Street, London, W.1. Dr. E. H. Allen will speak on "X-Ray Findings in Scurvy"; Dr. L. E. Glynn on "Vitamin C and Ground Substance" ; Dr. G. H. Bourne on "Vitamin $\mathrm{C}$ and Ossification"; and lastly Dr. B. E. Clayton on "Cortisone and Vitamin C".

ThE Ministry of Agriculture and Fisheries and the Department of Agriculture for Scotland propose to award, for the academic year beginning October 1, 1953, or earlier, a limited number of postgraduate scholarships in agricultural economics, husbandry, statistics, and agricultural and dairy engineering. The closing date for applications is May 1. Further particulars can be obtained from the Secretary, Ministry of Agriculture and Fisheries (Research Branch), 1-4 Cambridge Terrace, Regent's Park, London, N.W.1, or the Secretary, Department of Agriculture for Scotland, St. Andrew's House, Edinburgh 1 .

A ScIEnce Meeting of the Physical Society will be held at the Imperial College of Science and Technology, London, S.W.7, during May 15-16, the subject of which will be "Recent Research in Electron Optics". The meeting is being arranged by Dr. O. Klemperer, of the Imperial College, and will be divided into seven sections as follows: electron lenses; correction of aberrations; electron guns; focusing in electron accelerators; electron optics in television tubes and valves; electron spectrometry; other subjects. Visitors wishing to attend this meeting should apply to the offices of the Physical Society, 1 Lowther Gardens, Prince Consort Road, London, S.W.7, for further particulars; the closing date for applications is May 7. 